MUZIKOLOŠKI ZBORNIK - MUSICOLOGICAL ANNUAL X, LJUBLJANA 1974

UDK 781.61 Schönberg

\title{
STRUCTURE AND PROLONGATION: TONAL AND SERIAL ORGANIZATION IN THE "INTRODUCTION" OF SCHOENBERG'S VARIATIONS FOR ORCHESTRA ${ }^{1}$
}

\author{
Kenneth L. H i cke n (Lethbridge, Canada)
}

In its broader version this work represents an intensive study of pitch organization in the "Introduction" of Schoenberg's Variations for Orchestra, Op. 31. In keeping with the composer's wellknown assertion that his works were "twelve-note compositions, not twelve-note compositions", a prime objective of the investigation is "to gain greater insight into Schoenberg's serial music as - music". 3

The study concentrates upon three fundamental topics: (1) organization of pitch with reference to tonality; (2) organization of pitch with reference to the twelve-note series; and (3) correlation of serial and tonal organizational modes. Findings may be summarized as follows:

(1) Pitch in the Introduction is organized not only serially, but with reference to two simultaneous tonal centers a tritone apart, viz., $\mathrm{F}$ and $\mathrm{B}$, in accord with an extension of tonality which the writer terms the principle of "fused bitonality".

(2) The Introduction iz susceptible to structure-prolongation analysis (via a generalization of Schenkerian concepts). ${ }^{4}$ It readily reduces to a "fused-bitonal" Ursatz, and accordingly, may be understood as an elaborate prolongation of this Ursatz.

1 Cf. Kenneth L. Hicken, Structure and Prolongation: Tonal and Serial Organization in the "Introduction" of Schoenberg's Variations for Orchestra (Ph. D. dissertation, Brigham Young University, 1970).

2 Arnold Schoenberg Letters, selected and edited by Erwin Stein, translated by Eithne Wilkins and Ernst Kaiser (New York: St. Martin's Press, 1965), pp. 164-65. Date of letter: July 27, 1932.

3 Hicken, op. cit., p. 1.

${ }^{4}$ The writer's point of departure in making this generalization is the thought of Schenker as presented in the "Introduction" to Heinrich Schenker, Harmony, edited by Oswald Jonas, translated by Elisabeth Mann Borgese (Chicago, University of Chicago Press, 1954; 3rd impression, 1964), pp. XX-XXIV; and as extended by Felix Salzer in his Structural Hearing (New York: Charles Boni, 1952). 
(3) The Introduction's serial organization is also susceptible to a type of structure-prolongation analysis (via a further adaptation of Schenkerian concepts). The music's series-deployment pattern reduces to a "serial Ursatz", and may thus be viewed as a complex prolongation of this Ursatz.

(4) The serial Ursatz may be readily formulated as a prolongation of the fused-bitonal Ursatz.

In view of item "4", two very important inferences are drawn: (1) that the fused-bitonal Ursatz exists at a structurally more fundamental level than that of the serial Ursatz; and (2) that fused bitonality is therefore a more basic principle of pitch organization in the Introduction of Op. 31 than is the twelve-note technique. Accordingly, it is offered that Schoenberg's "method of composing with twelve tones which are related only with one another", 5 as encountered in the Introduction, is indeed a method, "a method used in effecting the unfoldment of the fundamental musical event contained in the fusedbitonal Ursatz". 6

Having outlined principal findings, it is now appropriate to to offer a more detailed presentation. The three fundamental topics under consideration, viz., tonal organization, serial organization, and correlation of serial and tonal modes of organization, will now be discussed in greater depth.

\section{"TONAL ORGANIZATION"7}

As is stated above, pitch in the Introduction of Op. 31 is organized with reference to two simultaneous tonal centers a tritone apart, viz., $F$ and $B$, in accord with the principle of fused bitonality. Thus, the music manifests concurrently an F-oriented and a B-oriented aspect. That element of the music having an $\mathrm{F}$ orientation, i. e., the aggregate of pitch-items organized with reference to $F$, is termed the music's "F component". Similarly, the element organized with reference to B is termed the music's "B component". These components are intimately interfused with each other, many items of one component belonging to the other component also. For this reason, the expression "fused bitonality" is employed.

The harmonic content of each component derives primarily from 19th Century chromatic practice, the principal tonal functions being those of the dominant and the tonic. In both components the dominant function is borne by a single six-note augmented-eleventh chord with minor ninth, $\mathrm{V}_{\mathrm{b} 9}^{\# 11}$, i. e., by one verticality (spelled CE G $\mathrm{Bb} \mathrm{Db} F$ \# in $\mathrm{F}$, and enharmonically respelled as $\mathrm{F} \# \mathrm{~A} \# \mathrm{C} \# \mathrm{E} \mathrm{G}$ $\mathrm{B} \#$ in $\mathrm{B}$ ) which functions in a dual capacity as the dominant of

${ }^{5}$ Arnold Schoenberg, Style and Idea (New York: Philosophical Library, 1950), p. 107.

6 Hicken, op. cit., p. 181.

7 Ibid., Chapter II, pp. 7-79. 
both keys. (When in a component this chord is inverted, with the eleventh in the bass, the Neapolitan function, bII, also achieves some prominence.) In each component the principal tonic chord is the major-minor tonic tetrad, $\mathrm{MmI}$ ( $\mathrm{F} \mathrm{Ab} \mathrm{A} \mathrm{\&} \mathrm{C}$ in $\mathrm{F}$ and $\mathrm{B} \mathrm{D}$ 与 $\mathrm{D} \#$ $\mathrm{F} \#$ in $\mathrm{B})$.

Because of each component's harmonic basis in primarily 19th Century practice, and because the Introduction as a whole may of course be viewed as a composite of its $F$ and $B$ components, many of the piece's verticalities are composites of tertian structures. Illustrations of such composites may be seen in Examples 1, 2, and 3, which follow shortly.

These examples are taken from a section of the dissertation in which the existence of the music's $F$ and $B$ components is demonstrated by presenting the components at the Schenkerian foreground level, in measure-for-measure alignment beneath a two-stave reduction of the Introduction itself.8,9 Important features of the tonal organization manifested in each example may be outlined as follows: ${ }^{10}$

(1) In the first example (meas. 18-21), ${ }^{11}$ the $F$ component contains a highly embellished movement from an inverted $\mathrm{V}^{\mathrm{b} 9}$ to a $\mathrm{V}_{\# 11}^{\mathrm{b} 13}$ in root position. The B component displays a complex prolongation of $\mathrm{V}_{\mathrm{b} 9}^{13}$ (meas. 18-21), and a resolution from $\mathrm{V}_{\# 11}^{13}$ to $\mathrm{MmI}$ co-inciding with a movement from $V_{\# 11}^{13}$ to $V^{\# 11}$ (meas. 20-21). The final verticality of this excerpt is an excellent illustration of a composite of tertian elements from the two components, i.e., a composite of $\mathrm{V}^{\mathrm{b} 13}$ of $\mathrm{F}$ (or $\mathrm{V}^{\# 11}$ of $\mathrm{B}$ ) and $\mathrm{MmI}$ of $\mathrm{B}$.

$$
\# 11
$$

(2) The second example (meas. 24-26) shows two resolutions over the $\mathrm{BACH}$ motive. The first resolution, involving the motive's

8 Ibid., pp. 20-37.

${ }^{9}$ In this paper, as in the dissertation, all excerpts from the Variations for Orchestra are used by permission of Belmont Music Publishers, Los Angeles, California 90049.

10 Abbreviations used in these examples include the following: "inc" (incomplete); " $\mathrm{H}$ " (horizontalized); " $\mathrm{h}$ " (partially horizontalized); " $\mathrm{Em}$ " (embelishment). A horizontal line separating two chord-symbols means that both chords represented exist essentially concurrently. Thus, for example, the concurrent existence of $\mathrm{V}_{\# 11}^{\# 11}$ and $\mathrm{MmI}$ is indicated by $\frac{\mathrm{MmI}}{\mathrm{V} \# 11}$. To signify an inversion of a chord, a numeral representing the chordmember in the bass is placed below the body of the chord symbol. Thus, in $\mathrm{V} \# 11$, the \#11 is in the bass.

${ }^{11}$ In this study, measure numbers cited in conjuction with examples may refer to incomplete as well as to complete measures. Thus, only a portion of meas. 18 appears in Example 1. 


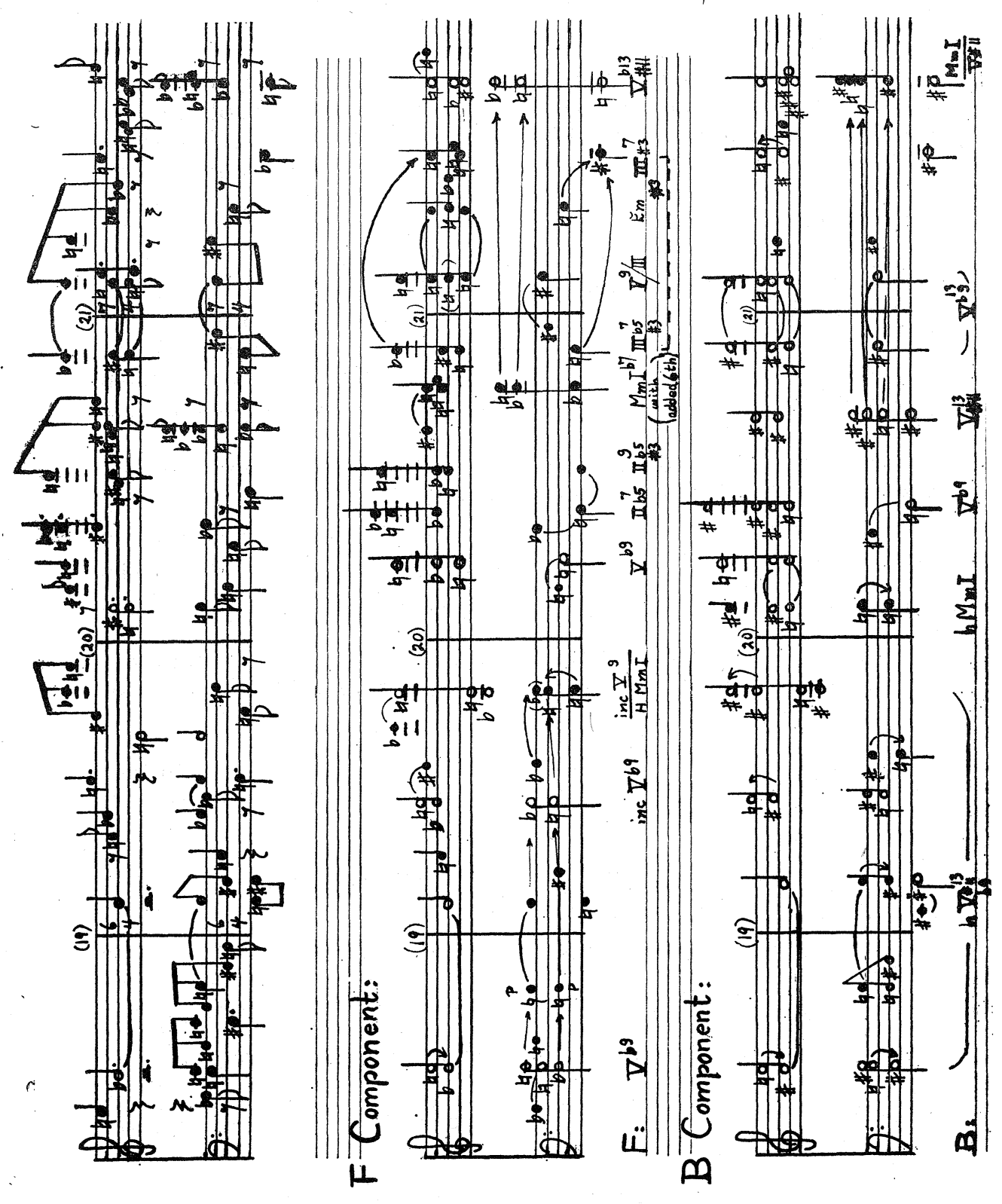

Example 1: Reduction and components 

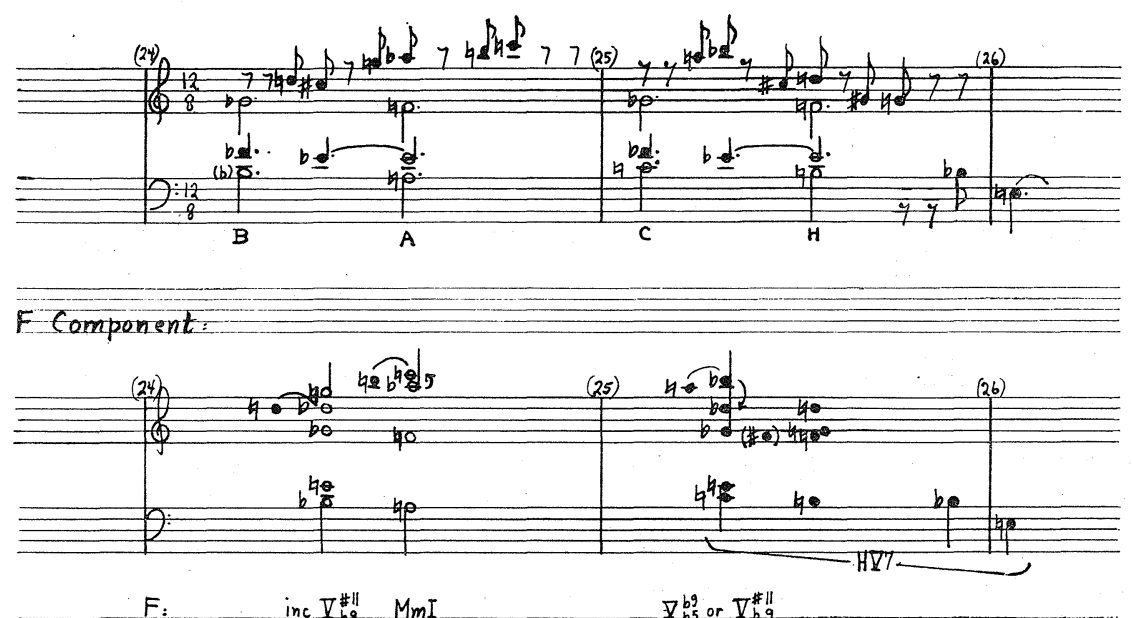

B Component:

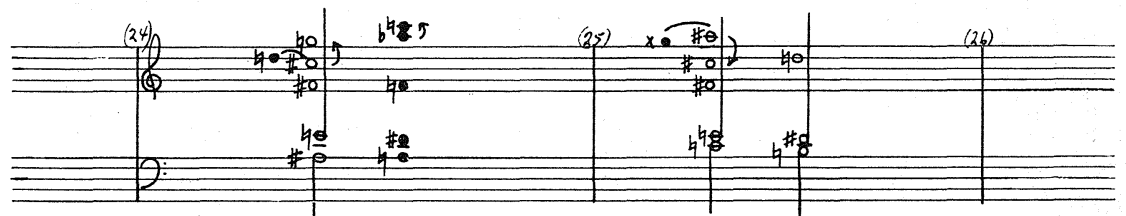

B:

$Z^{b 9} \mathrm{Em}$

$I^{\# \| 11}-M_{m} I$

Example 2: Reduction and components

first two notes, is from inc $\mathrm{V}_{\mathrm{b} 9}^{\# 11}$ to $\mathrm{MmI}$ in $\mathrm{F}$. The second resolution, involving the motive's second two notes, is from $\mathrm{V}^{\# 11}$ to $\mathrm{MmI}$ in $\mathrm{B}$.

(3) The third example (meas. 30-33), occurring at the conclusion of the Introduction, presents the penultimate and the final statement of $\mathrm{MmI}$ in $\mathrm{F}$, and portrays a terminal dominant-to-tonic progression in B. It also shows the Introduction's concluding verticality, a structure consisting of the roots and fifths of the $F$ and $B$ tonic tetrads.

Subsequent to the $\mathrm{F}$ and $\mathrm{B}$ components' foreground-level presentation in the dissertation, they are reduced, individually, via structure-prolongation analysis until the Ursatz of each is discovered. Then, by combining the two Ursätze, the Introduction's fused-bitonal Ursatz is arrived at, and the fundamental musical event incorporated in that Ursatz is determined.

The Ursatz of the F component consists of the harmonic pro. gression $\mathrm{V}_{\mathrm{b} 9}^{\# 11}-\mathrm{MmI}$ in $\mathrm{F}$ and of the melodic descent (Urlinie) $\mathrm{Bb}-\mathrm{Ab}$. The Ursatz of the $\mathrm{B}$ component consists of the harmonic 


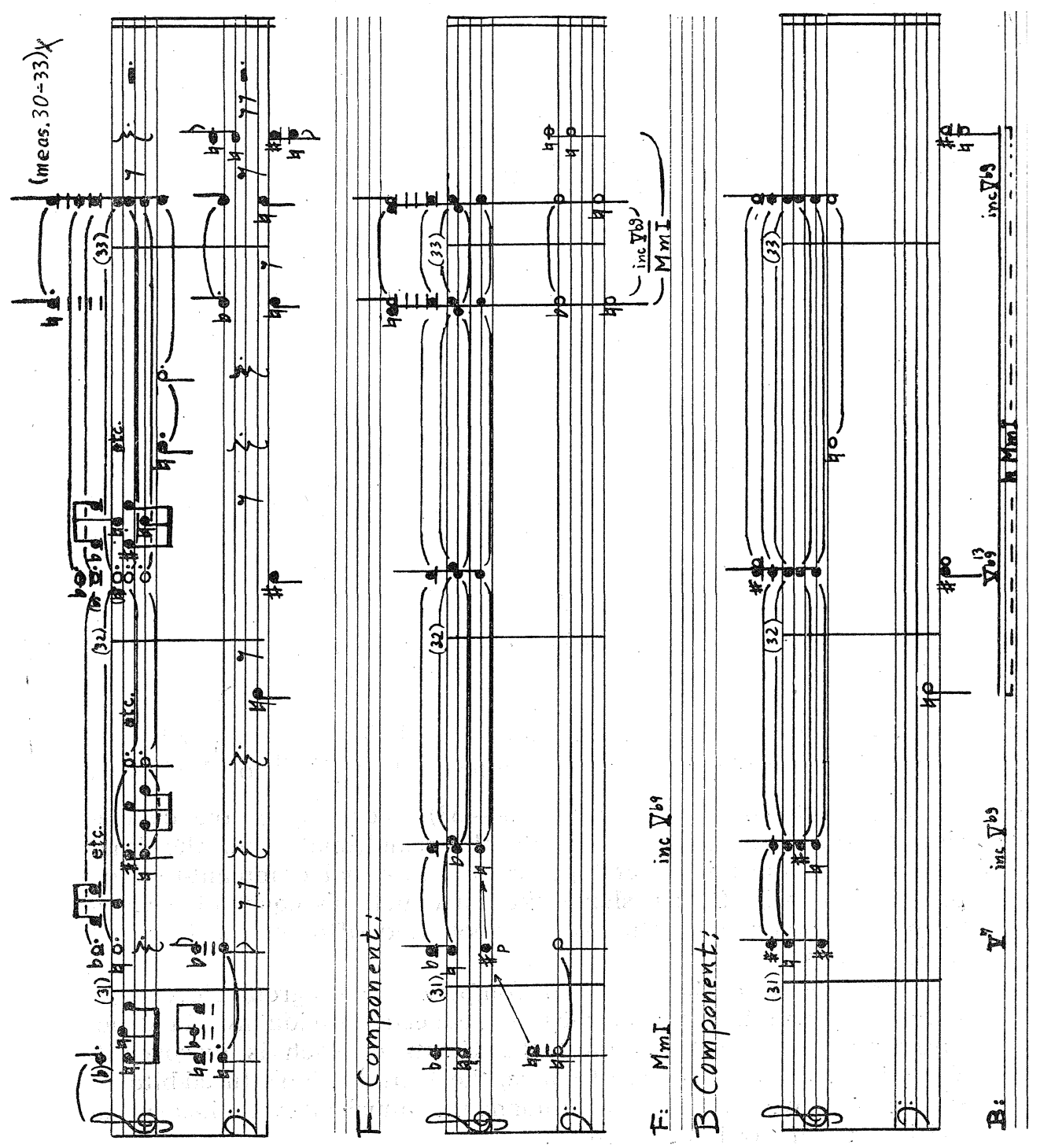

Example 3: Reduction and components 
progression $\mathrm{V}_{\mathrm{b} 9}^{\# 11}-\mathrm{MmI}$ in $\mathrm{B}$ and of the melodic descent $\mathrm{E}-\mathrm{D} \#$. The fused-bitonal Ursatz, as the integration of the F and B Ursätze, consists of (1) the harmonic progression from the six-note composite dominant of $\mathrm{F}$ and $\mathrm{B}\left(\mathrm{V}_{\mathrm{b} 9}^{\# 11}\right.$ of $\mathrm{F}, \mathrm{V}_{\mathrm{b} 9}^{\# 11}$ of $\left.\mathrm{B}\right)$ to a composite tonic of $\mathrm{F}$ and $\mathrm{B}(\mathrm{MmI}$ of $\mathrm{F}$ plus $\mathrm{MmI}$ of $\mathrm{B}$ ) and (2) the two melodic descents $\mathrm{Bb}-\mathrm{Ab}$ and $\mathrm{E}-\mathrm{D} \#$. This harmonic progression and the concomitant melodic descents constitute the fundamental musical event upon which the Introduction is based. The three Ursätze are represented in Example 4.

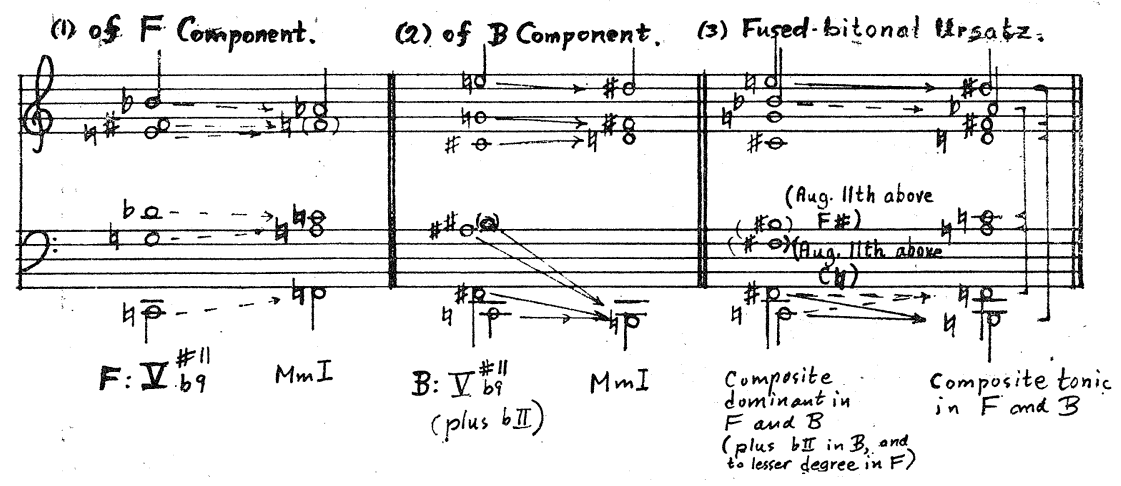

Example 4: Ursätze

The fundamental musical event's unfoldment at the foreground level takes place, of course, with reference to the design inherent in an intermediate-level (middleground) prolongation of the fusedbitonal Ursatz. This prolongation is shown in Example 5. Briefly, the design involves (1) prolongation of the composite dominant chord of $\mathrm{F}$ and $\mathrm{B}$, (2) resolution of this chord over the $\mathrm{BACH}$ motive, firstly in F (over "BA") and secondly in B (over " $\mathrm{CH}^{\prime}$ "), and (3) subsequent prolongation of the composite tonic chord.

The intermediate-level prolongation being fused bitonal in nature, readily divides into an $\mathrm{F}$ component and a $\mathrm{B}$ component. These are presented in Example 6.

\section{"SERIAL ORGANIZATION"12}

The duality and the susceptibility to structure-proiongation analysis manifested in the Introduction's tonal organization are parallelled by a duality and a susceptibility to structure-prolongation analysis to be found in the music's serial organization. More particularly,

${ }^{12}$ Hicken, op. cit., Chapter III, pp. 80-101. 


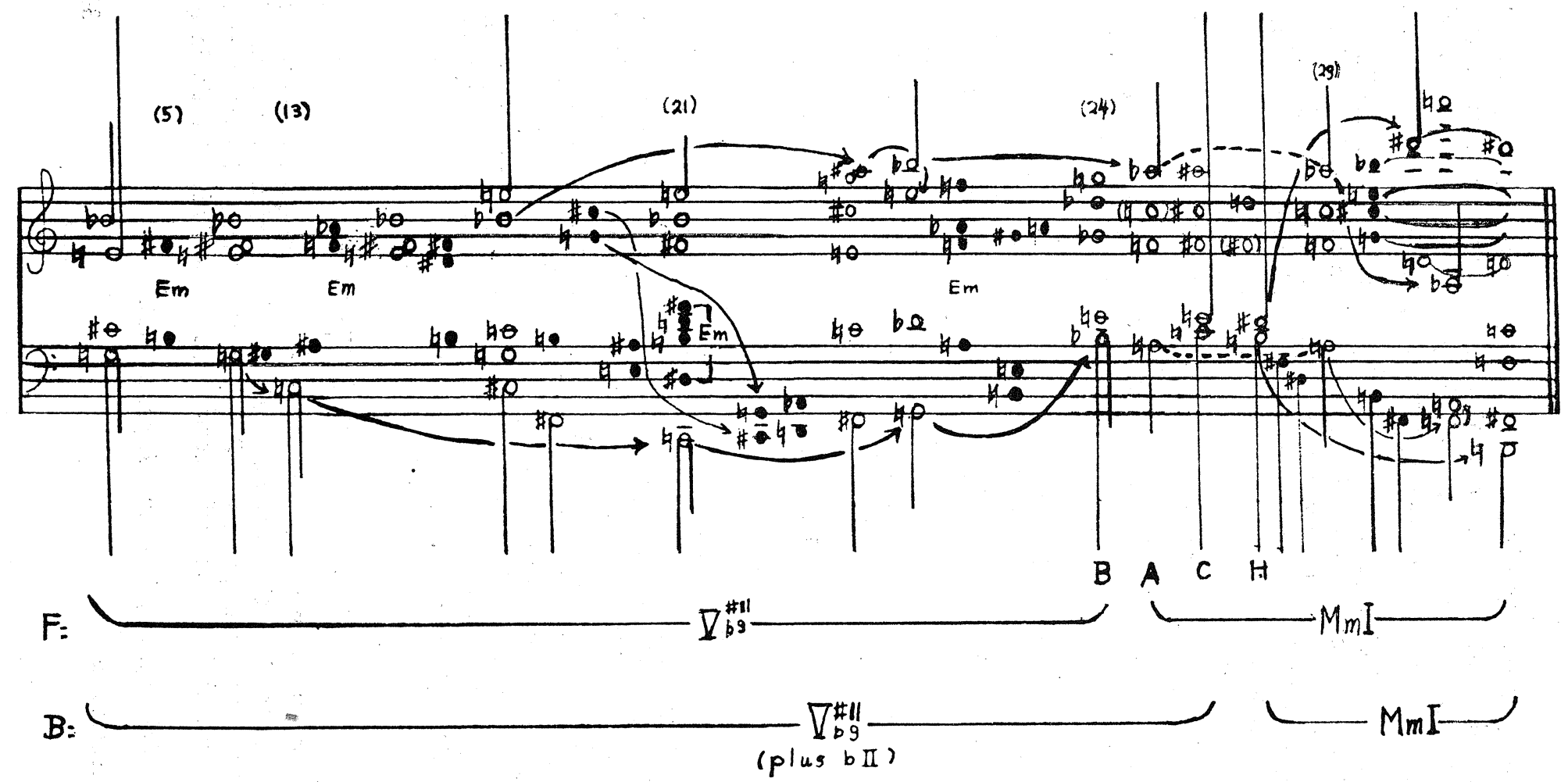

Example 5: Intermediate-level prolongation of fused-bitonal Ursatz 


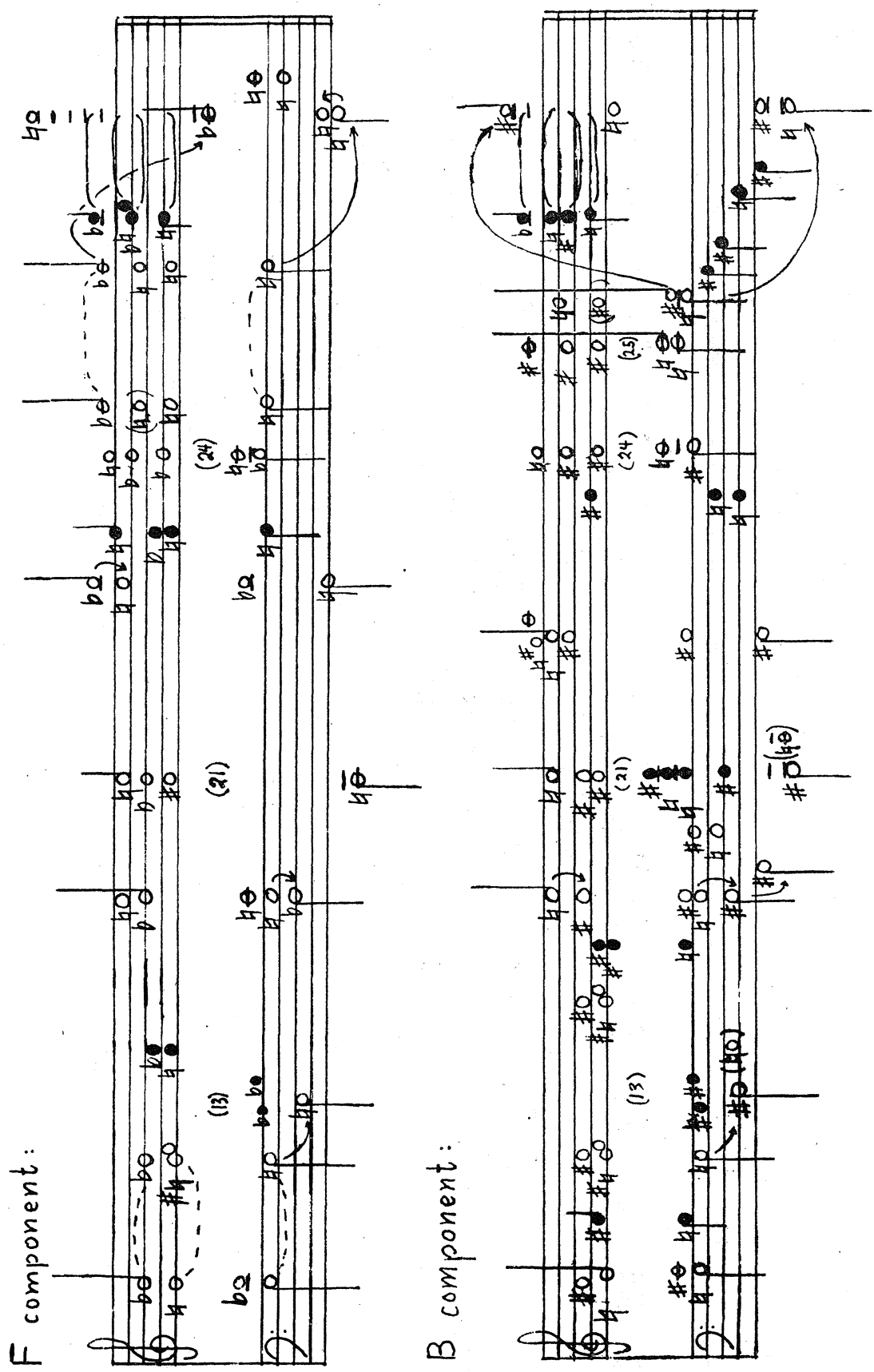

Example 6: $\mathrm{F}$ and $\mathrm{B}$ components of intermediate-level prolongation of fused-bitonal Ursatz 


\section{Measures:}

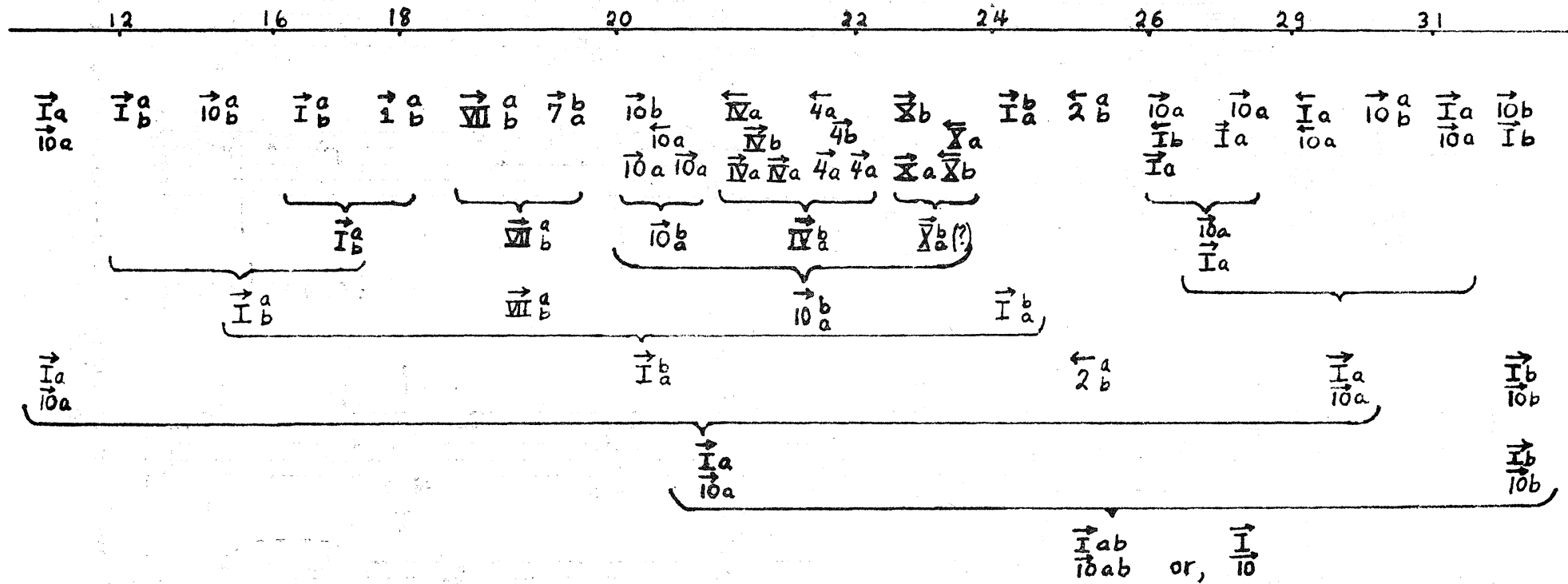


the over-all pattern according to which the series is deployed in the Introduction divides into two serial components and reduces substantially generalized structure-prolongation analysis to a bi-componential serial Ursatz. The structure-prolongation analysis of the deployment pattern is offered in Example 7. The deployment's serial. duality is demonstrated in Example 8.

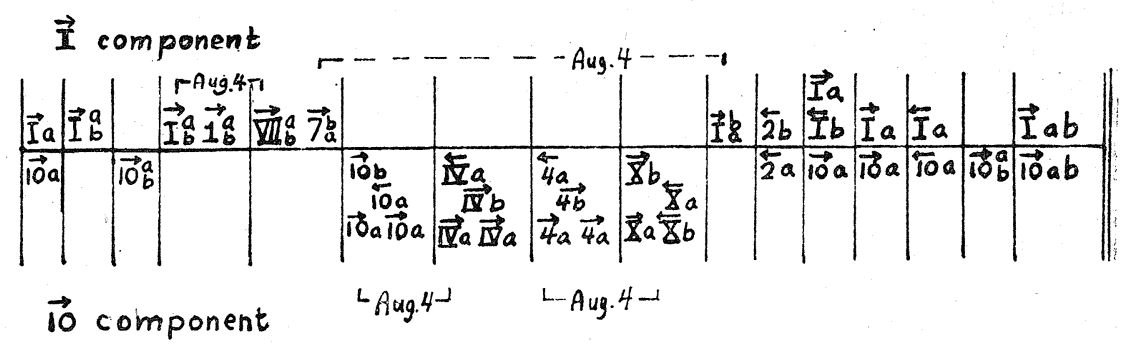

Example 8: Serial duality of series deployment

Symbols designating specific forms of the series encountered in the Introduction belong to a system Leibowitz used in his study of the Variations for Orchestra. ${ }^{13}$ According to this system, the basic set is represented by $\vec{I}$, the retrograde by $\overleftarrow{I}$, the inversion by $\vec{I}$, and the retrograde inversion by $\overleftarrow{1}$. Transposition of $\overrightarrow{\mathrm{I}}$ and $\overleftarrow{\mathrm{I}}$ are indicated by Roman numerals II-XII surmounted by arrows pointing to the right or to the left, and transpositions of $\overrightarrow{1}$ and $\overleftarrow{1}$ are indicated by Arabic numerals 2-12, again surmounted by appropriate arrows. Thus, for example, upwards transpositions of $\vec{I}, \overleftarrow{I}, \overrightarrow{1}$, and $\overleftarrow{1}$ by one, two, three, and four semitones, respectively, would be designated $\vec{I}$, III, $\overrightarrow{4}$, and $\overleftarrow{5}$, respectively, etc.

The serial "working unit" of the Introduction is the hexachord (i. e., the first or final half of a series-form). Antecedent hexachords are indicated by a suffix "a" (e. g., $\overrightarrow{10} \mathrm{a}$, the antecedent hexachord of $\overrightarrow{10}$ ); and consequent hexachords, by a suffix "b" (e.g., $\overrightarrow{\mathrm{IV}} b$, the consequent hexachord of $\overrightarrow{I V}$ ). In most cases, antecedent and consequent hexachords of a series-form occur simultaneously rather than consecutively. This arrangement is designated by means of both suffixes, one placed above the other (e.g., $7_{\mathrm{a}}^{\vec{b}}$ ).

In the deployment of the series, most of the hexachords are vertically paired (e.g., $\underset{10 a}{\overrightarrow{I a}}, \overleftarrow{2}{ }_{a}^{b}$, etc.). Such pairs are termed “deploy. 
ment units". Occasionally, a deployment unit contains more than two hexachords (e.g., ${ }^{\mathrm{IVa}} \overrightarrow{\mathrm{IVb}}$ ).

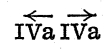

Reduction of the series deployment pattern to a serial Ursatz proceeds, as indicated earlier, via a substantial generalization of the structure-prolongational analytical approach. Two assumptions involved in this generalization are the following:

(1) that, analogously to the manner in which a group of chords (e. g., I-V-I) bounded by the same chord (i. e., I) may be viewed as a prolongation of that chord, a group of deployment units (e.g.,

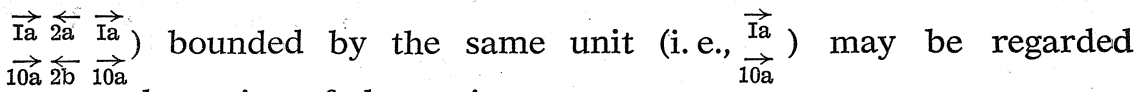
as a prolongation of that unit.

(2) that, analogously to the manner in which several different positions of a chord (e.g., $\mathrm{V}^{7}, \mathrm{~V}^{6}{ }_{5}, \mathrm{~V}^{4}{ }_{3}$, etc.) may be represented in a general sense by a single position (e.g., $V^{7}$ ), a group of deployment units (e.g., V $\overrightarrow{I I}_{b}^{a} \overrightarrow{7}_{a}^{b}$ ) concluding with an inversion $\left.\overrightarrow{(}_{a}^{b}\right)$ of the group's initial unit $\left(\overrightarrow{\mathrm{VI}} \mathrm{I}_{\mathrm{b}}^{\mathrm{a}}\right.$ ) may be represented, at a structurally more fundamental level, by that initial unit.

From Example 7 it may be seen that the serial Ursatz to which the series deployment pattern reduces is $\overrightarrow{10}(\overrightarrow{10}$ being the inversion of $\overrightarrow{\mathrm{I}}$ transposed upwards by a major sixth). The deployment pattern's

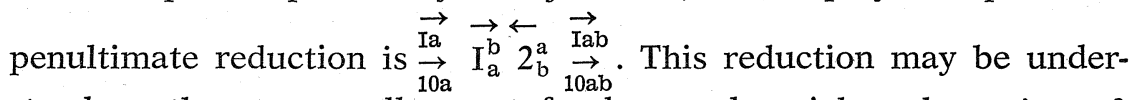
stood as the structurally most fundamental serial prolongation of this Ursatz.

The serial Ursatz, consisting of the two series-forms $\vec{I}$ and $\overrightarrow{10}$, manifests a serial duality which is reflected at the "foreground" level in the deployment pattern itself. As is shown in Example 8, this pattern divides into two components, one of which (termed the "I component") is based upon I, and the other of which (termed the "10 component") is based upon 10 .

\section{"A SERIAL-TONAL CORRELATION"14}

In keeping with the Introduction's susceptibility - both serially and fused-bitonally - to structure-prolongation analysis, it is fitting that correlation of the music's serial and tonal (more appropriately: fused-bitonal) modes of organization should be approached at several

1: René Leibowitz, Introduction à la musique de douze sons (Paris: L'Arche, 1949). Explanation of symbols: p. 121.

14 Hicken, op. cit., Chapter IV, pp. 102-178. 
structural levels. Accordingly, in the dissertation the matter is considered with reference to the foreground and Ursatz levels, and, to a lesser degree, with reference to an intermediate level. ${ }^{15}$

At the foreground level, correlation takes place essentially as specification of the portions of the $\mathrm{F}$ and $\mathrm{B}$ components associated with each series-deployment unit. To illustrate, three examples' are offered. The first of these, Example 9, is rather complex. The others, Examples 10 and 11, rare relatively simple.

\section{F Component:}

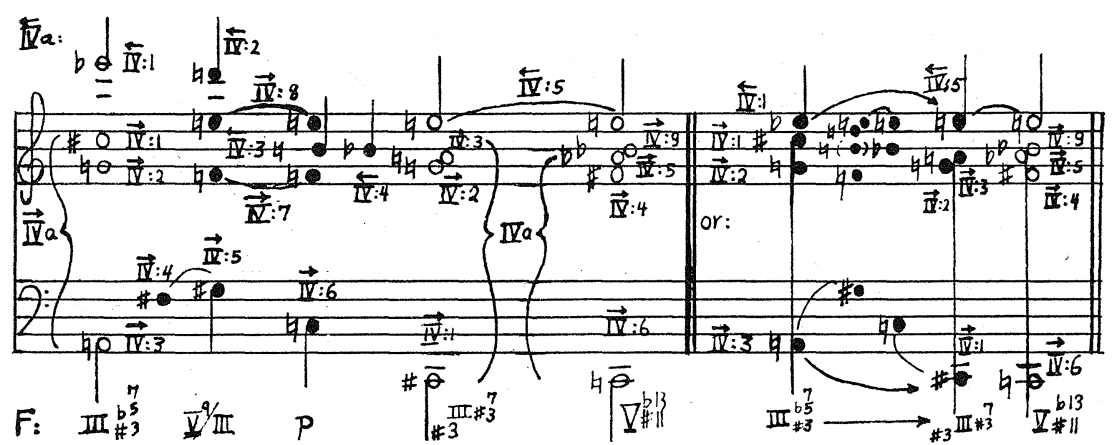

\section{B Component:}

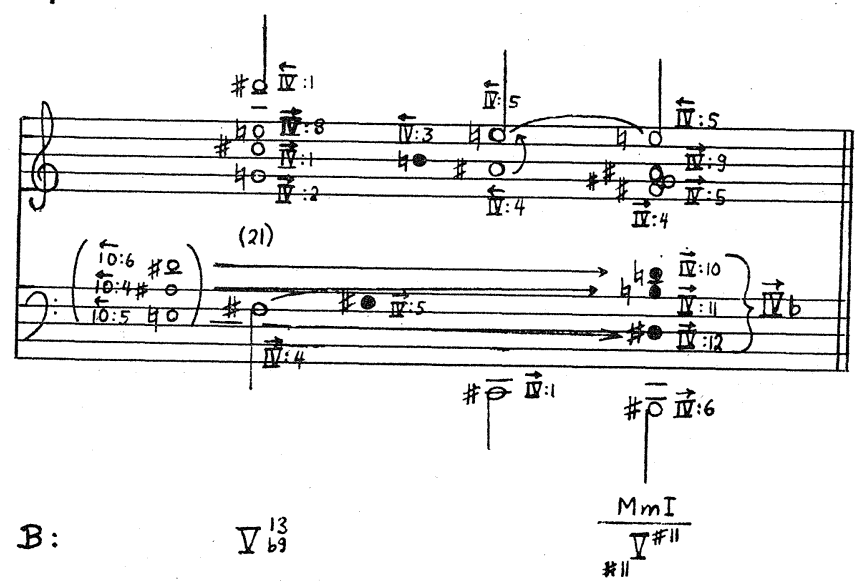

Example 9: Harmonies deriving from $\underset{\mathrm{IVa}}{\stackrel{\mathrm{IVb}}{\mathrm{IV} a}}$

${ }^{15}$ In the dissertation, the matter of the tonal significance of the serial Ursatz's serial duality receives brief attention as well. However, in the present paper, this topic is not discussed. 
Example 9 (meas. 20-21) shows harmonies in $\mathrm{F}$ and in $\mathrm{B}$ de-

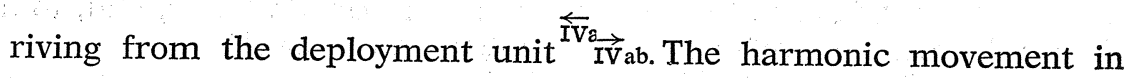
$\overrightarrow{I V} \vec{a} \vec{V} a$

F is from $\operatorname{III}_{3}^{7}$ to $\operatorname{IIII}_{\# 3}^{7}$ to $\mathrm{V}_{\# 11}^{\mathrm{b} 13}$. That in $\mathrm{B}$ is from $\mathrm{V}_{\mathrm{b} 9}^{13}$ to a composite of $\mathrm{MmI}$ and ${ }_{\# 11} \mathrm{~V}^{\# 11}$.

\section{F Component:}

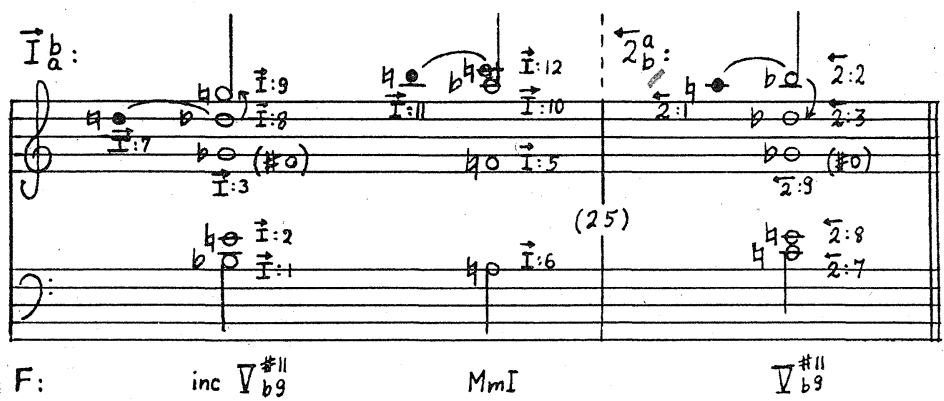

\section{B Component:}

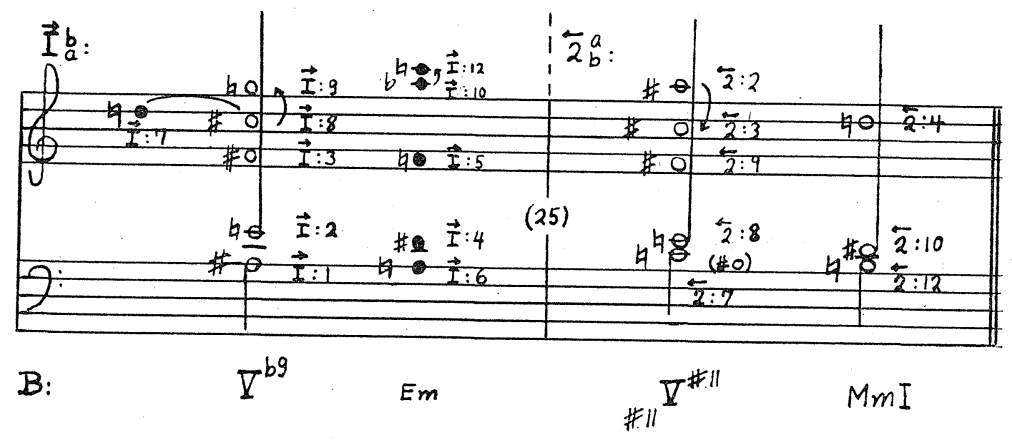

Example 10: F and B components associated with $\underset{I_{a}^{b}}{\vec{b}} 2 \underset{b}{\overleftarrow{a}}$

Example 10 (meas. 24-25) presents those portions of the $F$ and B components associated with $\overrightarrow{\mathrm{I}_{a}^{b}} 2 \stackrel{\overleftarrow{a}}{2}$, a two-unit group supporting the $\mathrm{BACH}$ motive. In $\mathrm{F}$, unit $\overrightarrow{\mathrm{I}_{\mathrm{a}}^{\mathrm{b}}}$ provides the progression inc $\mathrm{V}_{\mathrm{b} 9}^{\# 11}$ 40 
- MmI, over "BA" (Bb A); and unit $2_{b}^{\overleftarrow{a}}$ supports the progression $\# 11 \mathrm{~V}^{\# 11}-\mathrm{MmI}$, over " $\mathrm{CH}$ " ( $\mathrm{C}$ मे).

Example 11 (meas. 31-33) portrays sections of the $\mathrm{F}$ and $\mathrm{B}$ components deriving from $\underset{10 \mathrm{a}}{\overrightarrow{\mathrm{Iab}}} \overrightarrow{\mathrm{Ib}}$, the Introduction's two-unit ter-

F Component:
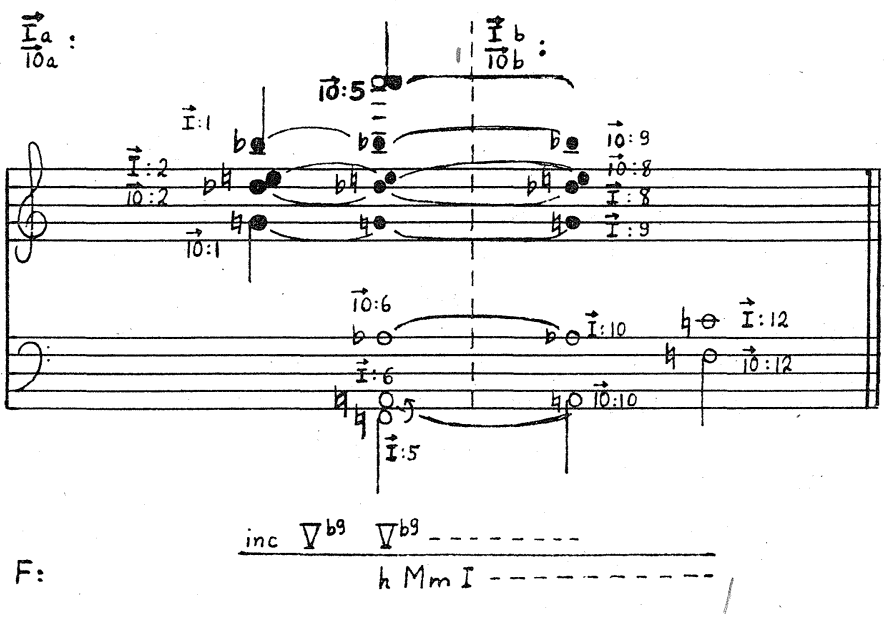

B Component:

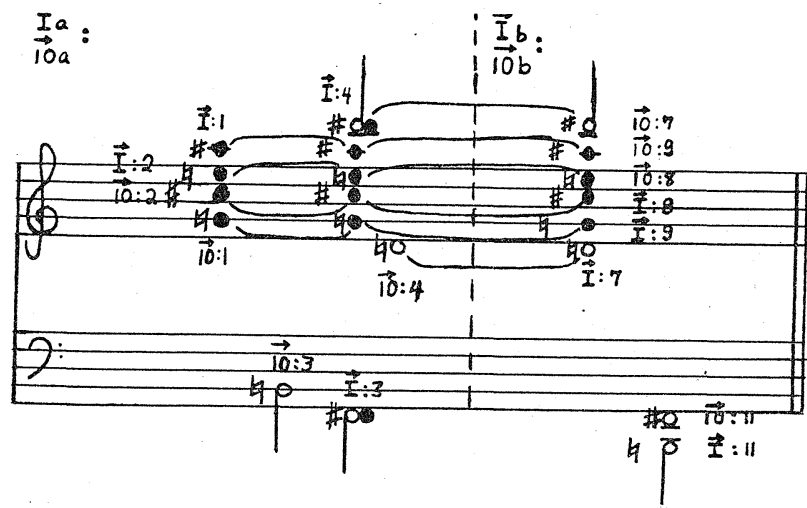

B: $\quad \frac{\text { inc } \bar{Z}^{b 9} \quad \nabla_{b 9}^{13} \quad \text { inc } \nabla_{b 9}}{h M m I \ldots}$

Example 11: F and B components associated with $\underset{\overrightarrow{I a}}{\overrightarrow{\mathrm{I}}} \overrightarrow{\mathrm{Ib}}$ 
minal group. In $F$, unit $\underset{10 a}{\overrightarrow{I a}}$ supplies an inc $\mathrm{V}^{\mathrm{b} 9}$, and an ensuing MmI and $\mathrm{a} \mathrm{V}^{\mathrm{b} 9}$ combined; and $\underset{10 \mathrm{~b}}{\overrightarrow{\mathrm{Ib}}}$ permits a continuation of both $\mathrm{V}^{\mathrm{b} 9}$ and $\mathrm{MmI}$, the latter being partially horizontalized in such a manner that its root and fifth constitute the $F$ component's final harmonic interval. In $\mathrm{B}$, unit $\underset{10 \mathrm{a}}{\overrightarrow{\mathrm{Ia}}}$ provides in inc $\mathrm{V}^{\mathrm{b} 9}$, a subsequent $\mathrm{V}_{\mathrm{b} 9}^{13}$, and a partial horizontalization of $\mathrm{MmI}$; and $\underset{10 \mathrm{~b}}{\overrightarrow{\mathrm{Ib}}}$ permits a continuation of inc $\mathrm{V}^{\mathrm{b} 9}$ and $\mathrm{MmI}$, the latter being partially horizontalized in such a fashion that its root and fifth constitute the B component's final harmonic interval.

Correlation at the Ursatz level proceeds primarily as a comparison of the fused-bitonal and serial Ursätze. This comparison of course has to take place on the basis of grounds common to both. Accordingly, in keeping with the note-order in the series-forms involved, the serial Ursatz is expressed as a fused-bitonal formulation patterned after the Introduction's underlying prolongational design. (See Example 5, above.)

That this fused-bitonal formulation is completely compatible with the nature of the harmonic and melodic proclivities harbored within the serial Ursatz may be readily demonstrated via the expression of this Ursatz as two "tonal components", one in F and the other in B, both of which are based upon tonic and dominant harmonies. The serial Ursatz and these two components are presented in Example 12.

The fused-bitonal formulation of the serial Ursatz appears in Example 13. Comparison of this formulation with the fused-bitonal Ursatz (which is also present in this example) reveals the former to be a prolongation of the latter. Accordingly, it is concluded that the serial Ursatz exists at a structurally less fundamental level than that of the fused-bitonal Ursatz, and that, in the Introduction, fused bitonality is therefore a more fundamental principle of pitch organization than is the twelve-note technique.

Correlation of the Introduction's serial and tonal modes of organization at the intermediate level involves a comparison of the series deployment pattern's penultimate reduction, $\underset{10 \mathrm{a}}{\overrightarrow{\mathrm{Ia}}} \overrightarrow{\mathrm{I}_{\mathrm{a}}^{\mathrm{b}}} \underset{2}{2} \underset{\mathrm{b}}{\stackrel{4}{\overrightarrow{\mathrm{Ia} a}}} \underset{10 \mathrm{a}}{\overrightarrow{\mathrm{Ib}}}$ (from Example 7, above), and the intermediate-level prolongation of the fused-bitonal Ursatz (presented as Example 5). In this contex, it is found that the serial reduction can be formulated fused-bitonally as a fair approximation of the intermediate-level prolongation. This formulation is offered in Example 14. 
Serial Ursatz:

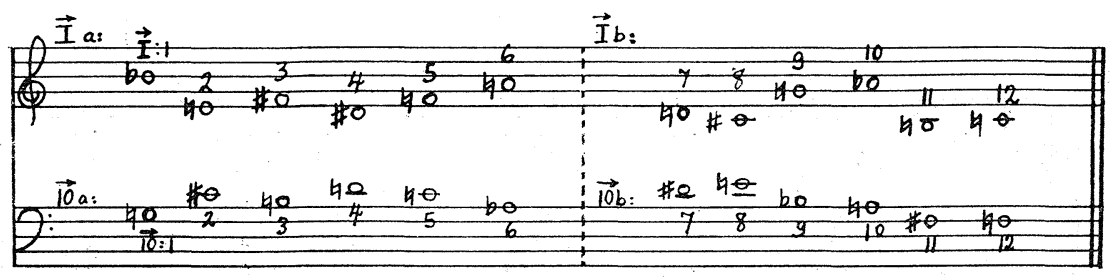

F Component:

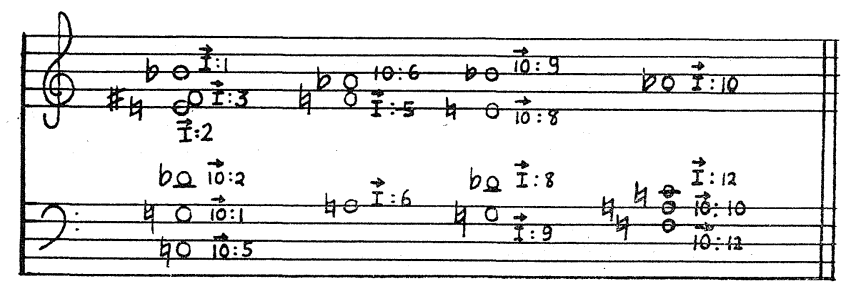

F: $\quad \nabla_{b q}^{\# \|} \quad$ inc MmI inc $\square^{b g} \quad \mathrm{MmI}$

B Component:

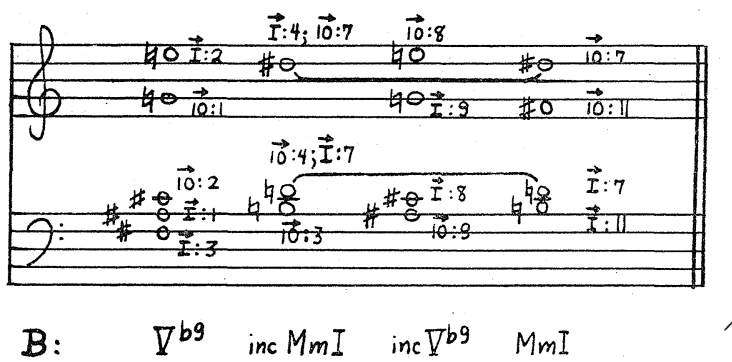

Example 12: Serial Ursatz and tonal components

\section{CONCLUDING REMARKS}

A prime objective of the dissertational study, as stated earlier in this paper, is to gain greater insight into Schoenberg's serial music as music. As an indication of the degree to which this objective is achieved with regard to the Introduction of Op. 31, the following points are offered: 

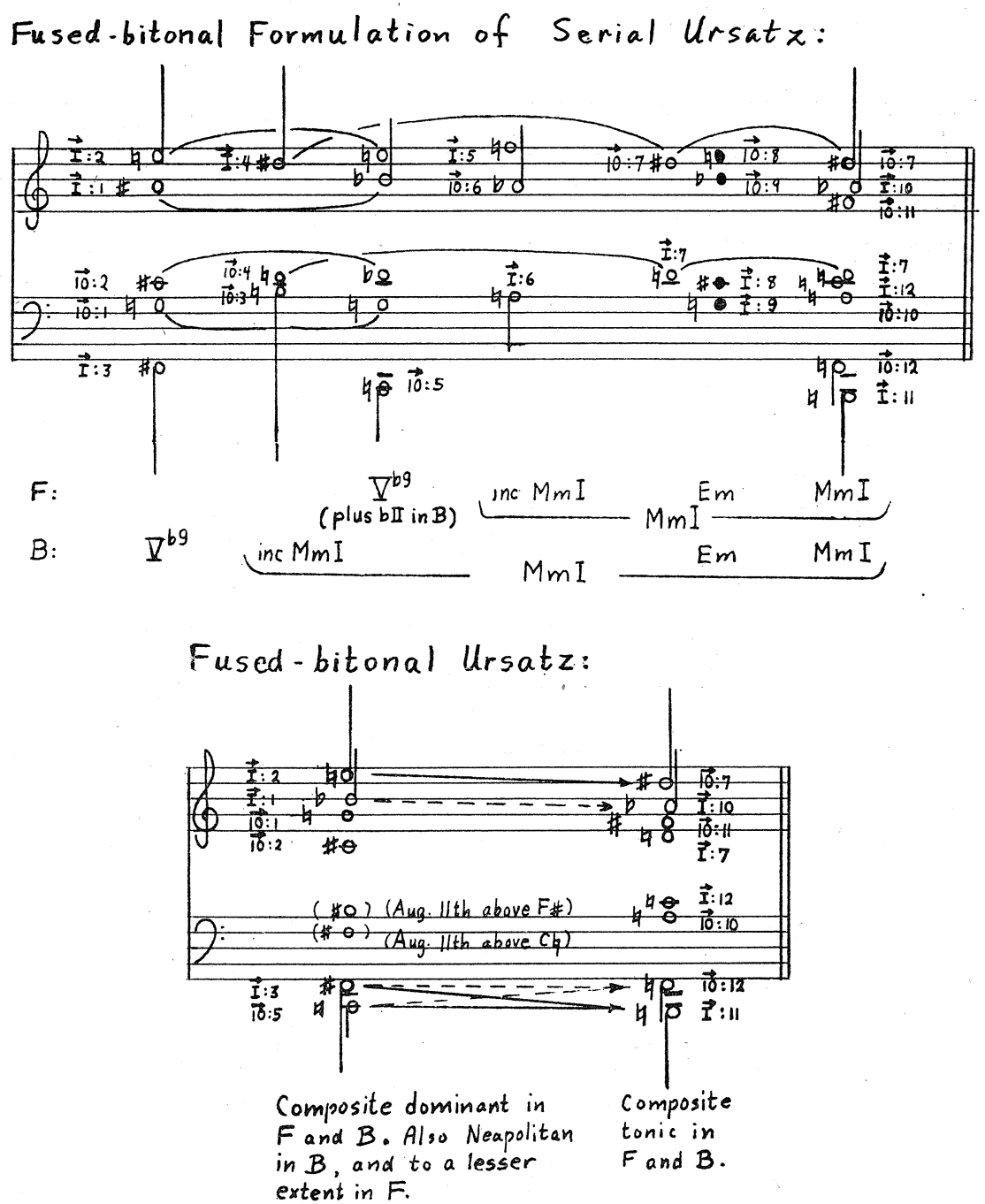

Example 13: Comparison of fused-bitonal formulation of serial Ursatz with fused-bitonal Ursatz

(1) The discovery that pitch in the Introduction of Op. 31 is organized with reference to the principle of fused bitonality provides a traditionally oriented basis upon which this excerpt's foreground-level harmonic vocabulary and syntax can be readily described. Accordingly, this music may be understood in terms of recognizable goaldirected harmonic and melodic motions.

(2) The discovery of this music's organization with reference to the principle of structure and prolongation affords a view of the 


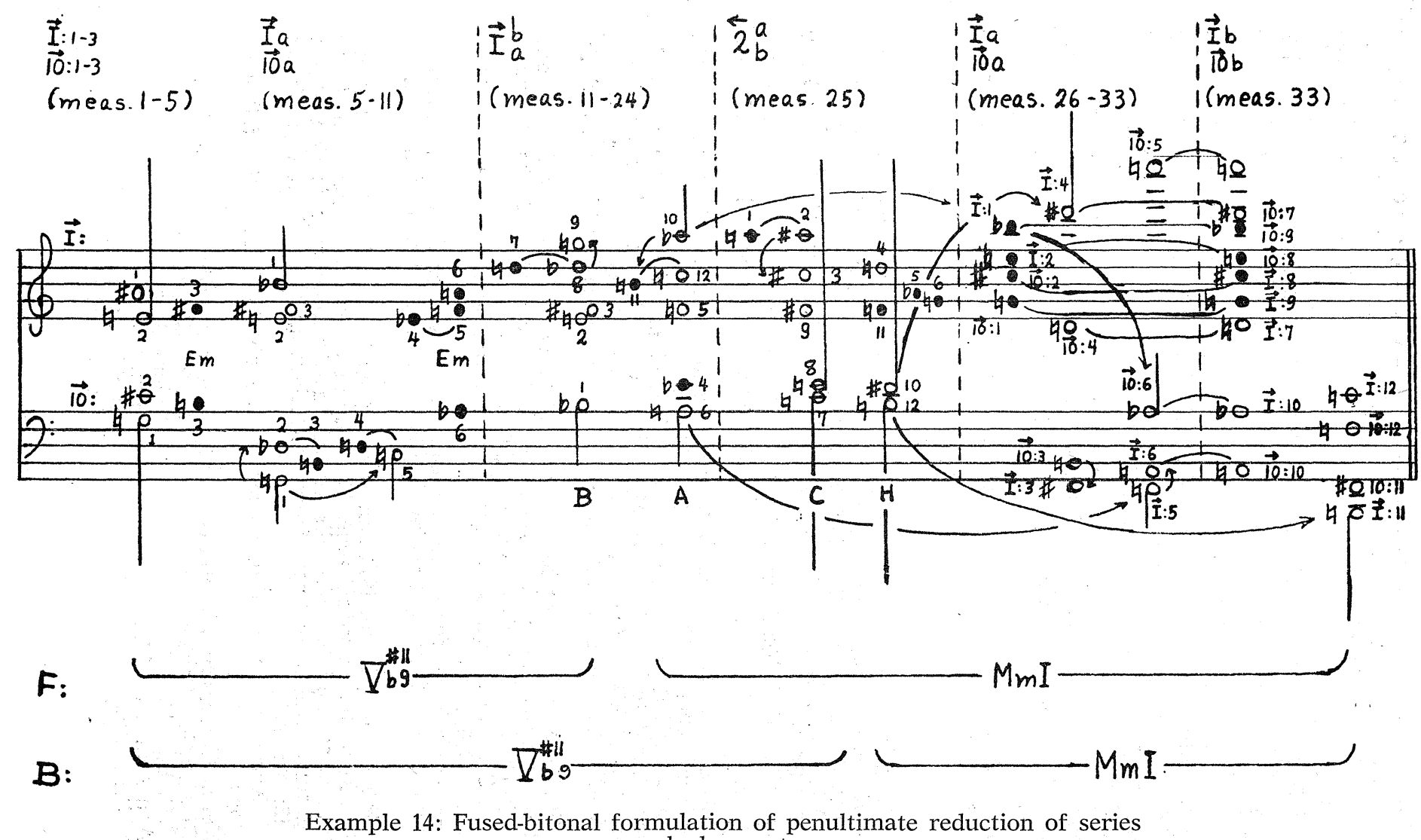
deployment 
Introduction - both fused-bitonally and serially - as an organic whole whose tonal and serial details have meaning within the context of the whole via their relationship to their respective Ursätze. In particular, the music's foreground-level harmonic and melodic subtleties my be understood as meaningful details in the unfoldment of the fundamental musical event contained in the fused-bitonal Ursatz.

The degree to which this study of the Introduction can increase insight into the musical qualities of the entirety of Schoenberg's serial oeuvre obviously depends upon the extent to which the principal findings of the study can be found to obtain in these works. Thus, intensive consideration of this music with regard to the findings of the study, and particularly, with reference to fused bitonality and to the principle of structure and prolongation, is advocated. In view of the fundamental nature of these findings, it is offered that such consideration may well prove to be emminently rewarding. ${ }^{16}$

\section{BIBLIOGRAPHY}

HICKEN, Kenneth L, Structure and Prolongation: Tonal and Serial Organization in the "Introduction" of Schoenberg's Variations for Orchestra. Ph. D. dissertation. Brigham Young University, 1970. 192 p. (Xerox. Microfilm. Ann Arbor, Michigan: Xerox University Microfilms. Order No. $71-8856.)^{17}$

LEIBOWITZ, René, Introduction à la musique de douze sons: Les Variations pour orchestre op. 31, d'Arnold Schoenberg. Paris: L'Arche, 1949. $351 \mathrm{p}$.

SALZER, Felix, Structural Hearing: Tonal Coherence in Music. 2 vols. New York: Charles Boni, 1952. 283; 349 p.

SCHENKER, Heinrich, Harmony. Edited and annotated by Oswald Jonas. Translated by Elisabeth Mann Borgese. Chicago: University of Chicago Press, 1954. Third impression, 1964. XXXII, 359 p. "Introduction", pp. V-XXIV, contains editor's discussion of concepts of Ursatz and Urlinie.

SCHOENBERG, Arnold, Arnold Schoenberg Letters. Selected and edited by Erwin Stein. Translated by Eithne Wilkins and Ernst Kaiser. New York: St. Martin's Press, 1965. 309 p.

-, Style and Idea. Edited by Dika Newlin. New Xork: Philosophical Library, 1950, $224 \mathrm{p}$.

-, Variationen für Orchester, Op. 31. Study score. Vienna: Universal Edition, c 1929. Copyright renewed 1956 by Gertrude Schoenberg. 80 p.

16 To date (March, 1974), the present writer has found the "Theme" of Op. 31 to be organized fused-bitonally at Schenkerian foreground and Ursatz levels and has also discovered fused-bitonal organization at the foreground level in excerpts from the following: Opp. 23 (No.5); 26; 30; $37 ; 42 ; 47 ; 50 \mathrm{~b}$.

17 Xerox and microfilm copies my be obtained from the following sources:

1) Xerox University Microfilms Dissertation Copies

P. O. Box 1764

Ann Arbor, Michigan

U S. A. 48106

2) University Microfilms Limited

St. Johns's Road

Tylers Green

High Wycombe

Buckingshamshire

England HP 10:8 HR 


\section{POVZETEK}

Osnovni namen razprave je, da poglobi na podlagi temeljite analize tonske organizacije $\mathrm{v}$ »Introdukciji« iz Schoenbergovih Variacij za orkester, op. 31, razumevanje skladateljeve serialne glasbe kot glasbe. Avtorjeve ugotovitve lahko formuliramo takole:

1. Tonske višine $\mathrm{v}$ »Introdukciji« niso organizirane le serialno, ampak tudi glede na dva tonalna centra, ki sta si oddaljena za zvečano kvarto, torej $\mathrm{v}$ smislu razširitve tonalnosti, ki jo označujemo kot načelo »fuzionirane bitonalnosti«. Zato lahko omenjeno glasbo razumemo v smislu harmonskega in melodičnega gibanja, ki je spoznavno usmerjeno proti cilju.

2. »Introdukcija« je organizirana po načelu strukture in prolongacije, zaradi česar jo je mogoče pojmovati - glede na fuzionirano bitonalnost in serialnost - kot organsko celoto, katere tonski in serijski detajli imajo smisel $\mathrm{v}$ kontekstu celote $\mathrm{z}$ ozirom na odnos do njihovih jeder. Posebno eminentne harmonske in melodične finese lahko razumemo kot brezpomembne detajle $\mathrm{v}$ razvoju osnovnega glasbenega dogajanja, kot je vsebovano v fuzioniranem bitonalnem jedru.

Koliko lahko pričujoče preučevanje "Introdukcije poglobi razumevanje muzikalnih kvalitet celotnega Schoenbergovega serialnega opusa, je očitno odvisno od obsega, $v$ katerem bi ugotovitve razprave veljale tudi za druga skladateljeva dela. Zato avtor priporoča intenzivno preučevanje Schoenbergove ustvarjalnosti $\mathrm{z}$ vidika fuzionirane bitonalnosti in glede na princip strukture in prolongacije. Spričo dosedanjih ugotovitev je mogoče domnevati, da bi takšno preučevanje koristno rezultiralo. 